\title{
Abundance and distribution of the swimming crab Callinectes danae Smith, 1869 (Crustacea, Decapoda, Portunidae) in the Ubatuba region, southeastern Brazil
}

\author{
Mariana Antunes, Vivian Fransozo, Giovana Bertini, Gustavo Monteiro \\ Teixeira \& Adilson Fransozo
}

To cite this article: Mariana Antunes, Vivian Fransozo, Giovana Bertini, Gustavo Monteiro Teixeira \& Adilson Fransozo (2015) Abundance and distribution of the swimming crab Callinectes danae Smith, 1869 (Crustacea, Decapoda, Portunidae) in the Ubatuba region, southeastern Brazil, Marine Biology Research, 11:9, 920-932, DOI: 10.1080/17451000.2015.1044998

To link to this article: https://doi.org/10.1080/17451000.2015.1044998

\section{曲 Published online: 07 Aug 2015.}

\section{Submit your article to this journal $\sqsubset$}

Џ Article views: 69

View Crossmark data ¿

Citing articles: 1 View citing articles $\longleftarrow$ 


\title{
Abundance and distribution of the swimming crab Callinectes danae Smith, 1869 (Crustacea, Decapoda, Portunidae) in the Ubatuba region, southeastern Brazil
}

\author{
MARIANA ANTUNES $^{1 \star}$, VIVIAN FRANSOZO ${ }^{1,2}$, GIOVANA BERTINI $^{1,3}$, \\ GUSTAVO MONTEIRO TEIXEIRA ${ }^{1,4} \&$ ADILSON FRANSOZO $^{1}$
}

\begin{abstract}
${ }^{1}$ NEBECC Study Group on Crustacean Biology, Ecology and Culture, Departamento de Zoologia, Instituto de Biociências, Universidade Estadual Paulista, Botucatu, Brazil, ${ }^{2}$ Universidade Estadual do Sudoeste da Bahia, Vitória da Conquista, Brazil, ${ }^{3}$ Universidade Estadual Paulista, Registro, Brazil, and ${ }^{4}$ Departamento de Biologia Animal e Vegetal, Universidade Estadual de Londrina, Londrina, Brazil
\end{abstract}

\begin{abstract}
This study analysed the spatio-temporal distribution of Callinectes danae considering some environmental factors in three bays in Ubatuba, São Paulo, Brazil: Ubatumirim, Ubatuba and Mar Virado. Sampling was performed monthly (from January 1998 to December 1999) using a shrimp fishery boat provided with double rig nets. Six transects were established in each bay, three being in areas protected from wave action (at 5, 7.5 and $10 \mathrm{~m}$ depth) and three in exposed areas (at 10, 15 and $20 \mathrm{~m}$ ). A total of 3039 specimens were obtained. The distribution of $C$. danae differed between years, among seasons, bays and transects $(\mathrm{K}-\mathrm{W} ; p<0.05)$. This species occurred with a higher abundance in the shallow transects of all bays studied. These transects were characterized by substrate composed of fine or very fine sand and by silt and clay, higher values of bottom temperature and lower salinity values. Based on canonical correspondence analysis, the most relevant environmental factors for the spatio-temporal distribution of $C$. danae, in addition to salinity, were the bottom-water temperature and the sediment texture.
\end{abstract}

Key words: Brachyura, environmental factors, South Atlantic, temporal and spatial distribution

\section{Introduction}

Portunids of the genus Callinectes live in marine and estuarine areas of the Atlantic American coast and are commonly found inhabiting shallow coastal waters (Williams 1974; Powers 1977; $\mathrm{Ng}$ et al. 2008). They are very important along the Brazilian coast due to their high abundance and ecological significance as predators and voracious hunters in the estuarine-marine ecosystem. They also serve as a food resource for other aquatic organisms such as fish and coastal birds (Haefner 1990; Mantelatto \& Fransozo 1997).

The swimming crab Callinectes danae Smith, 1869 is distributed in the Western Atlantic from Florida to Argentina, occurring in estuarine, coastal and oceanic waters, with records at $70 \mathrm{~m}$ depth, in brackish or hypersaline environments (Norse 1977; Buchanan \& Stoner 1988; Melo et al. 1989; Costa \& Negreiros-Fransozo 1998; Sforza et al. 2010). It is an exploited species along the Brazilian coast, frequently caught by artisanal fishery in coastal communities (Severino-Rodrigues et al. 2001; Sforza et al. 2010) and by the commercial penaeidean shrimp fishery (Loebmann \& Vieira 2006; Keunecke et al. 2008).

The first bioecological observations for $C$. danae on the southern and southeastern Brazilian coast were conducted by Branco et al. (1992) and Negreiros-Fransozo \& Fransozo (1995), and the distributional patterns and reproductive studies were addressed in Branco \& Masunari (2000),

${ }^{\star}$ Correspondence: Mariana Antunes, NEBECC Study Group on Crustacean Biology, Ecology and Culture, Departamento de Zoologia, Instituto de Biociências, Universidade Estadual Paulista, Campus de Botucatu, Botucatu, Brazil. E-mail: mariana@ibb.unesp.br 
Chacur et al. (2000), Chacur \& Negreiros-Fransozo (2001), Baptista-Metri et al. (2005) and Sant'Anna et al. (2012).

Worldwide estimations indicate that the bycatch fauna amount is at least five times greater than the catch for fishery production (Clucas 1998). This is one of the major concerns of the FAO due to the considerable protein loss (FAO 1994). Among the groups that comprise the shrimp fishery bycatch in the state of São Paulo, Brazil, brachyuran crustaceans are prominent in both biomass and species diversity (Severino-Rodrigues et al. 2001). Thus, Mantelatto \& Fransozo (1999) already reported on the disappearance of the portunid population from the São Paulo coast and suggested the need for frequent monitoring. Some stocks, such as in the Santos area, have undergone reductions (SeverinoRodrigues et al. 2001), requiring studies aimed at informing specific public bodies to protect these populations (Sant'Anna et al. 2012).

The life cycle, its demographics and the spatial distribution of swimming crabs of the genus Callinectes is complex. Williams (1974), Norse (1977), Paul (1982) and Lipcius \& Van Engel (1990) reported that the distribution of swimming crabs in estuarine areas reflects a wide tolerance to low salinities. However, Buchanan \& Stoner (1988) suggested that the distribution pattern of Callinectes species is also the result of complex intra- or interspecific interactions among other congener species. Fransozo et al. (1992), McClintock et al. (1993), Negreiros-Fransozo \& Fransozo (1995) and Carvalho \& Couto (2011) studied biological aspects related to the distribution, abundance, habitat and migration of Callinectes species on the Atlantic coast, and verified that the juveniles of the majority of the species inhabit estuaries, whereas mature females conserve energy in low-salinity environments to spawn before subsequently migrating with a welldeveloped egg mass to more saline waters, offshore, where the larvae hatch.

Studies carried out on the southeastern Brazilian coast to date have only been performed in restricted areas, such as estuaries or single bays. Comparisons over a wider area, with several sampling sites, including many estuaries and bays, are not available in the literature for this region. An analysis of the distributional pattern variations of a species' population in relation to the environmental fluctuations on a wider scale might raise a more general hypothesis on the mechanisms that modulate such population features.

This study aimed to analyse the differential distribution of $C$. danae in three bays of the northern coast of the state of São Paulo, southeastern Brazilian, which are characterized by a distinct physiography and conservation status.

\section{Materials and methods}

Study area

The Ubatuba region is characterized by innumerable spurs of the coastal mountains ('Serra do Mar') that form an extremely indented coastline (Ab'Saber 1955). The exchange of water and sediment between the coastal region and the adjacent shelf is very limited (Mahiques 1995). The region is under the influence of three water masses: Coastal Water $\left(\mathrm{CWa}=\right.$ temperature $>20^{\circ} \mathrm{C}$; salinity $\left.<36\right)$, Tropical Water $\left(\mathrm{TW}=\right.$ temperature $>20^{\circ} \mathrm{C}$; salinity $>$ 36), and South Atlantic Central Water (SACW = temperature $<18^{\circ} \mathrm{C}$; salinity $<36$ ) (Castro-Filho et al. 1987; Odebrecht \& Castello 2001; De Léo \& Pires-Vanin 2006).

During late spring and early summer, the SACW penetrates into the bottom layer of the coastal region and forms a thermocline over the inner shelf located at depths of $10-15 \mathrm{~m}$ (Castro-Filho et al. 1987). During winter, the SACW retreats to the shelf break and is replaced by the CWa. As a result, no stratification is present over the inner shelf during the winter months (Pires 1992; Pires-Vanin \& Matsuura 1993). The sediment is composed of fine or very fine sand and silt and clay, given the low water movement within the bay and between the bay and the adjacent continental shelf (Mahiques et al. 1998).

The sampled bays (Figure 1) present contrasting physiographic features, both regarding their configuration and the orientation of river discharge. The Ubatumirim Bay faces southwest with several small islands close to its mouth. The islands are considered physical shields, such that the region is subjected to less intense hydrodynamics, which results in the deposition of fine sediments (Mahiques 1995). The bay receives freshwater inflow mainly from the Puruba, Ubatumirim and Fazenda Rivers, and is an area of lower occupancy and human activity in the region (Rodrigues et al. 2002). Ubatuba Bay faces the east and presents a seaward constriction formed by rocky projections, thus delimiting a shallower inner area and an outer area with a maximum depth exceeding $10 \mathrm{~m}$ (Mahiques 1995). The input of fluvial sediments is strongly dependent on the rainfall regime (Mahiques et al. 1998), leading to a higher contribution during the summer season. Four rivers flow into the bay and greatly influence its water quality (CETESB 1996), especially during rainy periods when large amounts of untreated sewage are introduced from Ubatuba City. The seaward end of Mar Virado Bay faces the southeast, 


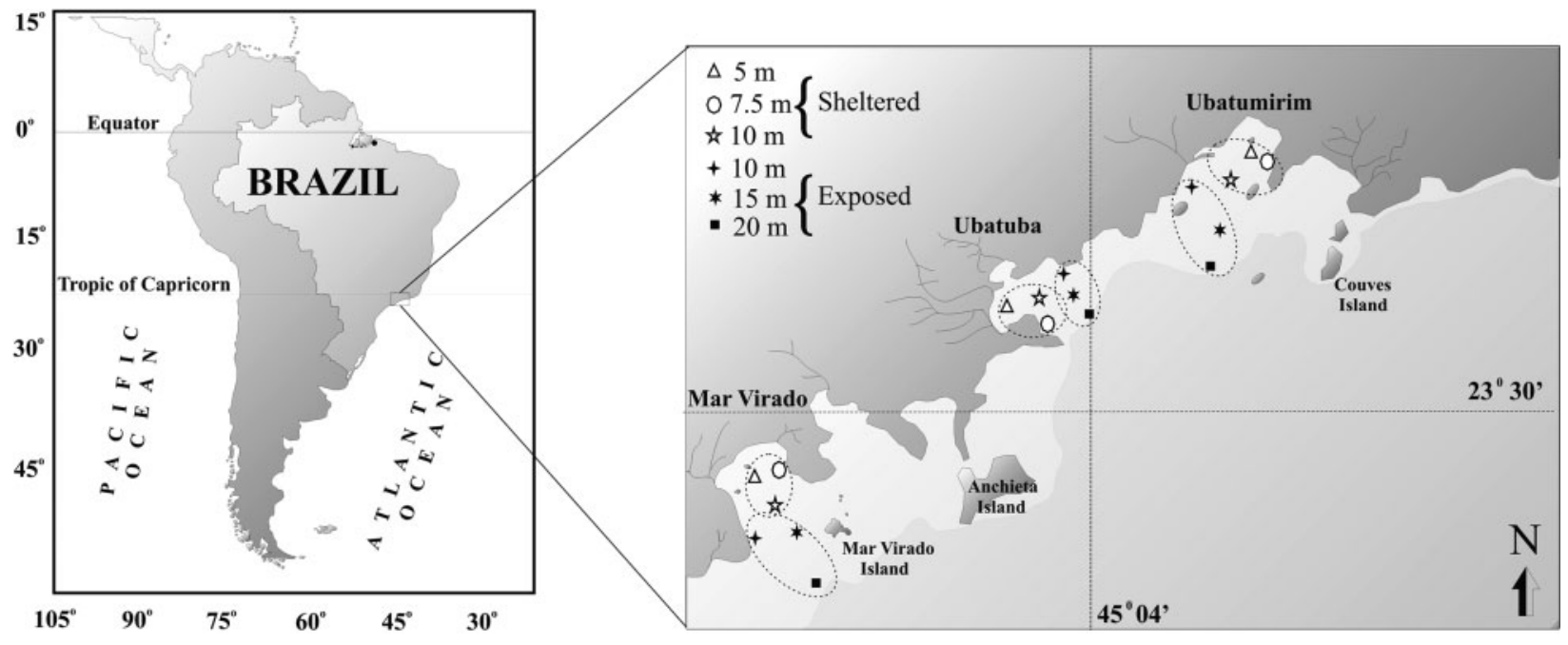

Figure 1. Map of the Ubatuba region on the northern coast of São Paulo State, southeastern Brazil, showing sampling areas and transects.

and Mar Virado Island is situated at the eastern border of the bay mouth. The predominant substrate is composed of sediment from two rivers: Lagoinha and Maranduba (Mahiques 1995).

\section{Swimming crab sampling and environmental features}

Swimming crabs were collected monthly, from January 1998 to December 1999 from the Ubatumirim (UBM), Ubatuba (UBA) and Mar Virado (MV) Bays on the northern coast of the state of São Paulo, Brazil (Table I). Six transects were established in each bay, three being in areas protected from wave action (at 5, 7.5 and $10 \mathrm{~m}$ depth) and three in exposed areas (at 10,15 and $20 \mathrm{~m}$ depth) (Figure 1).

Each transect was sampled using a commercial shrimp fishery boat equipped with a double-rig, using a main net with a $20 \mathrm{~mm}$ mesh and a terminal cod net with a $15 \mathrm{~mm}$ mesh. Trawls were carried out for $30 \mathrm{~min}$ each, sampling a total area of approximately $18,000 \mathrm{~m}^{2}$.

Swimming crabs were identified according to Melo (1996); their sex was determined by abdominal morphology, and the major carapace width (CW) was measured, as well as the lateral teeth, using callipers $(0.1 \mathrm{~mm})$. All specimens were classified into demographic groups: $\mathrm{JM}=$ juvenile males, $\mathrm{AM}=$ adult males, $\mathrm{JF}=$ juvenile females, $\mathrm{AF}=$ adult females, $\mathrm{OF}=$ ovigerous females, and $\mathrm{NO}=$ adult non-ovigerous females. The distinction between adult and juveniles was made based on Haefner (1990).

The abiotic data were collected from the midpoint of each transect, at the end of each trawl, with a stationary boat, while the trawl nets were brought onto the deck and the biological material screened. Salinity and temperature $\left({ }^{\circ} \mathrm{C}\right)$ were recorded from bottom-water samples obtained with a Nansen bottle. Depth was measured in each transect using an ecobathymeter coupled with a GPS (geographic positioning system). Substrate samples were

Table I. Station information for trawls taken between January 1998 and December 1999 in bays along the northeastern coast of São Paulo State, Brazil: depths and coordinates (south latitude; west longitude). Ubatumirim (UBM), Ubatuba (UBA) and Mar Virado (MV). 10 S: 10 m Sheltered. 10 E: 10 m Exposed.

\begin{tabular}{|c|c|c|c|c|c|c|}
\hline \multirow[b]{2}{*}{ Bay } & \multicolumn{6}{|c|}{ Station depth (m) } \\
\hline & 5 & 7.5 & $10 \mathrm{~S}$ & $10 \mathrm{E}$ & 15 & 20 \\
\hline \multicolumn{7}{|l|}{$U B M$} \\
\hline Latitude (S) & $23^{\circ} 21^{\prime} 18^{\prime \prime}$ & $23^{\circ} 21^{\prime} 45^{\prime \prime}$ & $23^{\circ} 23^{\prime} 00^{\prime \prime}$ & $23^{\circ} 22^{\prime} 00^{\prime \prime}$ & $23^{\circ} 24^{\prime} 00^{\prime \prime}$ & $23^{\circ} 25^{\prime} 20^{\prime \prime}$ \\
\hline Longitude (W) & $44^{\circ} 54^{\prime} 20^{\prime \prime}$ & $44^{\circ} 53^{\prime} 36^{\prime \prime}$ & $44^{\circ} 54^{\prime} 48^{\prime \prime}$ & $44^{\circ} 56^{\prime} 40^{\prime \prime}$ & $44^{\circ} 55^{\prime} 00^{\prime \prime}$ & $44^{\circ} 55^{\prime} 15^{\prime \prime}$ \\
\hline \multicolumn{7}{|l|}{$U B A$} \\
\hline Latitude (S) & $23^{\circ} 26^{\prime} 33^{\prime \prime}$ & $23^{\circ} 26^{\prime} 48^{\prime \prime}$ & $23^{\circ} 26^{\prime} 10^{\prime \prime}$ & $23^{\circ} 25^{\prime} 16^{\prime \prime}$ & $23^{\circ} 26^{\prime} 42^{\prime \prime}$ & $23^{\circ} 27^{\prime} 12^{\prime \prime}$ \\
\hline Longitude (W) & $44^{\circ} 03^{\prime} 15^{\prime \prime}$ & $44^{\circ} 02^{\prime} 12^{\prime \prime}$ & $45^{\circ} 01^{\prime} 36^{\prime \prime}$ & $45^{\circ} 00^{\prime} 57^{\prime \prime}$ & $44^{\circ} 59^{\prime} 57^{\prime \prime}$ & $44^{\circ} 58^{\prime} 45^{\prime \prime}$ \\
\hline \multicolumn{7}{|l|}{$M V$} \\
\hline Latitude (S) & $23^{\circ} 32^{\prime} 03^{\prime \prime}$ & $23^{\circ} 32^{\prime} 07^{\prime \prime}$ & $23^{\circ} 33^{\prime} 36^{\prime \prime}$ & $23^{\circ} 34^{\prime} 21^{\prime \prime}$ & $23^{\circ} 35^{\prime} 00^{\prime \prime}$ & $23^{\circ} 36^{\prime} 13^{\prime \prime}$ \\
\hline Longitude (W) & $45^{\circ} 12^{\prime} 18^{\prime \prime}$ & $45^{\circ} 11^{\prime} 14^{\prime \prime}$ & $45^{\circ} 11^{\prime} 32^{\prime \prime}$ & $45^{\circ} 12^{\prime} 30^{\prime \prime}$ & $45^{\circ} 10^{\prime} 20^{\prime \prime}$ & $45^{\circ} 08^{\prime} 11^{\prime \prime}$ \\
\hline
\end{tabular}


collected using a Van Veen grab $\left(0.06 \mathrm{~m}^{2}\right.$ in area) and the samples used to analyse the organic matter content and granulometric composition. Each sample was placed in a plastic bag, tagged and frozen to minimize the decomposition of organic matter.

The sediment for granulometric analysis was separated into two samples of $50 \mathrm{~g}$ each and 250 $\mathrm{ml} \mathrm{NaOH}(0.2 \mathrm{~N})$ was added to suspend silt and clay. The subsamples were washed through a sieve (mesh size $=0.063 \mathrm{~mm}$ ) that only allowed the silt and clay fraction to pass. The remaining sediment was dried and submitted to graduated sieving (see Wentworth 1922).

Measures of central tendency (phi) were used to determine which of the grain-size fractions was most frequent in the sediment, based on the percentages in each transect. These values were based on the graphical depiction of the cumulative frequencydistribution curves of the sediments based on the phi scale (phi $=-\log _{2}$ of the diameter of the grain in $\mathrm{mm}$ ), and the following classes were obtained: $-1=$ phi $<0$ (gravel); $0=$ phi $<1$ (coarse sand); $1=$ phi $<$ 2 (medium sand); $2=$ phi $<3$ (fine sand); $3=$ phi $<$ 4 (very fine sand); and phi $\geq 4$ (silt and clay). From these values, measurements of central tendency were calculated to determine the most frequent granulometric fractions in the sediment samples. These values were calculated from the data extracted from the cumulative curves of frequency distribution of such sediment samples. Finally, the values corresponding to the 16 th, 50 th and 84 th percentiles were used to determine the mean diameter (MD) using the formula: $\mathrm{MD}=\left(\mathrm{MD}_{16}+\mathrm{MD}_{50}+\mathrm{MD}_{84}\right) / 3$ (Suguio 1973).

The organic matter content of the sediment was estimated as the difference between the initial and final ash-free dry weights of three subsamples $(10 \mathrm{~g}$ each) incinerated in porcelain crucibles at $500^{\circ} \mathrm{C}$ for $3 \mathrm{~h}$. Details concerning the analysis of environmental factors can be found in Bertini et al. (2001) and Almeida et al. (2012).

\section{Data analyses}

Non-parametric analyses were performed because our data did not present a normal distribution (ShapiroWilk, $p>0.05$ ) or homoscedasticy (Levene's test). The abundance was compared concerning its spatial (among bays, areas and transects) and temporal (seasons - summer: January-March; autumn: AprilJune; winter: July-September; spring: OctoberDecember) distribution, using a Kruskal-Wallis test, followed by an 'a posteriori' Dunn test, adopting a significance level of 0.05 (Zar 1999).

The abundance of species in each demographic group was also evaluated using a canonical correspondence analysis (CCA) $(\alpha=0.1)$ that was performed using R Development Core Team (v. 2006). The mean value of species abundance and the environmental factors were calculated for each demographic group for each month. Alternative data transformations were tested with respect to their capacity to improve the normality of the data; the $\ln$ $(1+x)$ was the most appropriate transformation based on the lowest Kolmogorov-Smirnov's D (more details in Castilho et al. 2008a, 2008b). The CCA is a statistical multivariate procedure that measures the association power between two variable groups. The first group of variables included the environmental features (bottom-water temperature and salinity, organic matter content and sediment texture), whereas the second group of variables included the species abundance (AM, AF, NO, $\mathrm{OF}, \mathrm{JM}$ and $\mathrm{JF}$ ).

\section{Results}

The greatest variation in bottom temperature during the study period occurred in the summer and spring of both years. The variation during summer was from 20.5 to $27.5^{\circ} \mathrm{C}$, and during spring from 17.9 to $24.2^{\circ} \mathrm{C}$, when significant differences were observed between exposed and sheltered areas, among transects, and among bays (Table II). With respect to bottom salinity, the greatest variation occurred in the spring of 1998 and 1999 at UBM (from 32.2 to 35.1 ) and in the winter (from 31.7 to 35.5), and in both years at UBA and MV during spring (from 32.9 to 35.6$)$.

The analysis of the temperature-salinity (T-S) diagram showed three water masses acting throughout all seasons in all studied bays. The CWa was predominant (CWa: $T>20^{\circ} \mathrm{C}, S<36$ ), characterized by low salinity and high temperatures. During the spring, the SACW (SACW: $T<18^{\circ} \mathrm{C}, S<36$ )

Table II. Results of the Kruskal-Wallis test for bottom-water temperature and salinity on transects in Ubatumirim, Ubatuba and Mar Virado, São Paulo State, Brazil.

\begin{tabular}{lclll}
\hline & & \multicolumn{1}{c}{$\begin{array}{c}\text { Bottom-water } \\
\text { temperature }\end{array}$} & & \multicolumn{1}{c}{$\begin{array}{c}\text { Bottom-water } \\
\text { salinity }\end{array}$} \\
\cline { 3 - 3 } \cline { 5 - 5 } & Year & DF / test values & & DF / test values \\
\hline Bays & 1998 & $2 / H=1.45$ & & $2 / H=0.60$ \\
& 1999 & $2 / H=0.39$ & & $2 / H=22.53^{\star}$ \\
Area & 1998 & $5 / H=19.92^{\star}$ & & $5 / H=4.96$ \\
Transects & 1999 & $5 / H=9.91$ & & $5 / H=33.24^{\star}$ \\
& 1998 & $5 / H=47.45^{\star}$ & & $5 / H=8.86$ \\
Seasons & 1999 & $5 / H=24.25^{\star}$ & & $5 / H=18.55^{\star}$ \\
& 1998 & $3 / H=65.47^{\star}$ & & $3 / H=58.62^{\star}$ \\
& 1999 & $3 / H=135.42^{\star}$ & & $3 / H=36.23^{\star}$ \\
\hline
\end{tabular}

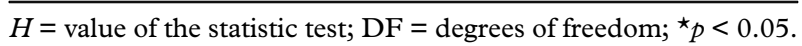



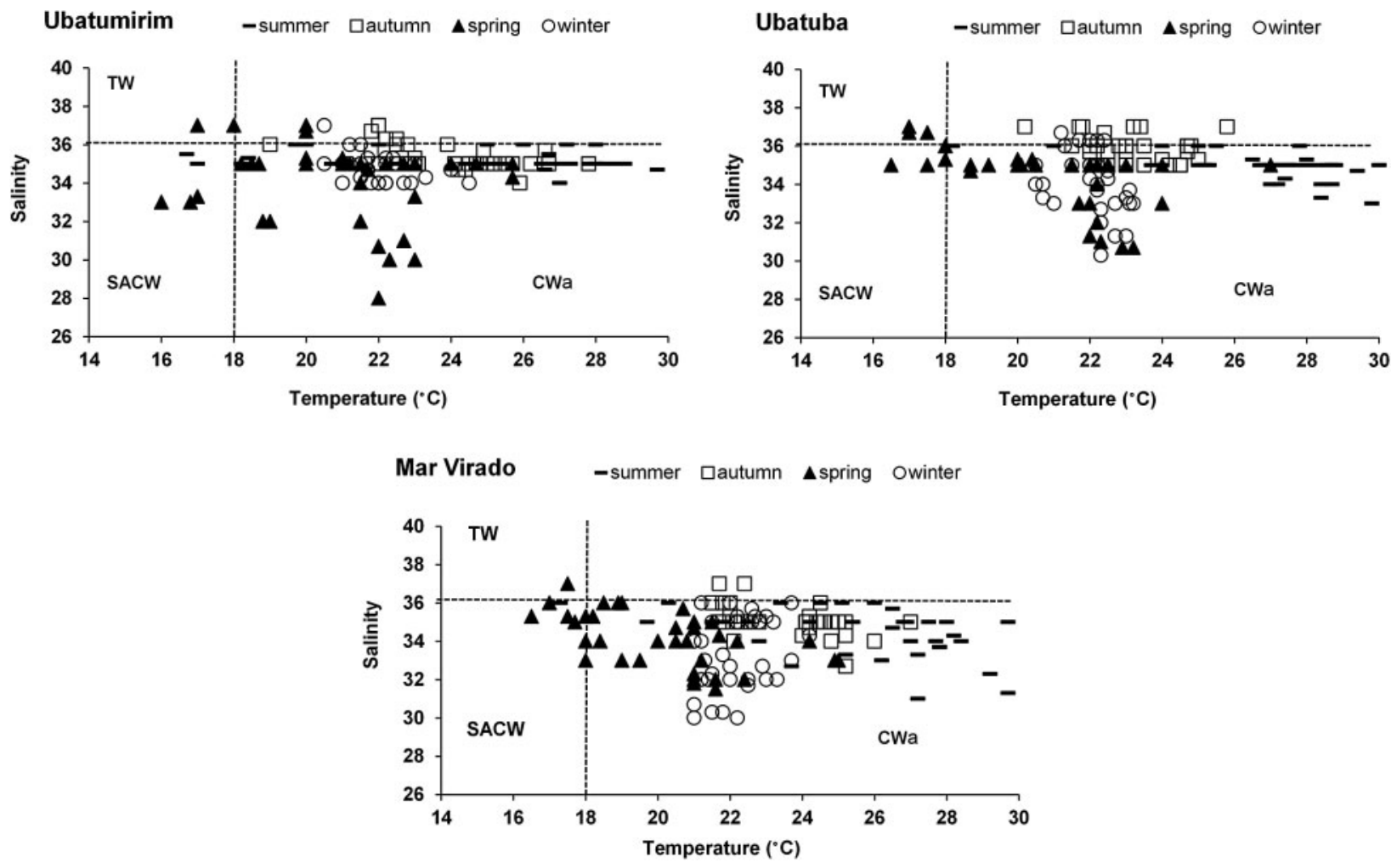

Figure 2. T-S diagrams of the temporal variation in bottom-water temperature and salinity during the sampling period (January 1998December 1999) at Ubatumirim, Ubatuba and Mar Virado, São Paulo State, southeastern Brazil. CWa, Coastal Water; TW, Tropical Water; SACW, South Atlantic Central Water.

was detected at the UBA and MV bays, whereas it was less evident in the summer at UBM (Figure 2).

The grain diameter varied among transects and bays, but there was a predominance of fine sand, very fine sand and silt and clay in all sampled areas. There was a higher percentage of silt and clay in the north-south direction (from UBM to MV), which comprised more than $70 \%$ of the sediment in almost all transects of the MV. The highest percentage of organic matter content in the sediment was found at the UBA $(5.9 \%)$, followed by MV (4.5\%) and UBM $(3.6 \%)$. The lowest mean of organic matter content in the sediment $(2.9 \%)$ and phi value (3.0) were recorded at $20 \mathrm{~m}$ depth (exposed), whereas the highest mean of organic matter content $(6.2 \%)$ and phi value (5.3) was at a depth of $10 \mathrm{~m}$ (sheltered). In general, there was a trend for a higher concentration of organic matter in the substrata that contained finer grains (Figure 3).

The higher abundance of Callinectes danae was associated with higher temperatures: from $25^{\circ} \mathrm{C}$ to $28^{\circ} \mathrm{C}$ at the UBM and MV bays, and from $28^{\circ} \mathrm{C}$ to $31^{\circ} \mathrm{C}$ at the UBA bay. The association of the abundance and bottom temperature was significant at UBM and UBA (UBM: $H=26.190, \mathrm{DF}=4$, $p<0.001$; UBA: $H=17.411, \mathrm{DF}=4, p=0.002)$.
There was no association between the abundance of swimming crabs and salinity (Figure 4 ).

The highest concentration of swimming crabs occurred in the intermediate size classes of organic matter content of sediment at UBM and UBA; however, at MV the highest abundance was observed in the size class that comprised the superior organic matter content. Nevertheless, a significant difference among the organic matter content classes was only observed in UBM $(H=22.786, \mathrm{DF}=4$, $p<0.001)$. However, individuals concentrated at sites with the highest values of phi as follows: at UBM in the classes from 4 to $5(H=108.733, \mathrm{DF}=$ $5, p \leq 0.001)$, at UBA and MV in the classes from 5 to 6 (UBA: $H=73.648, \mathrm{DF}=5, p<0.001, \mathrm{MV}$ : $H=49.051, \mathrm{DF}=5, p<0.001)$.

A total of 3039 specimens of $C$. danae were obtained from 144 trawls; 1611 in 1998 and 1428 in $1999(H=24.494, \mathrm{DF}=5, p=0.001)$. The highest abundance was recorded at UBM (1485), where the mean number of individuals (123.7) differed significantly from that of the other bays $(H=22.486, \mathrm{DF}=2, p=0.001)$. The UBA bay showed the second-highest abundance value (1048), followed by MV (506).

With respect to bathymetry, the highest abundance of $C$. danae occurred in both years along the 
⿴囗十 $\quad$ B $\square C$ OPhi $\triangle O M$

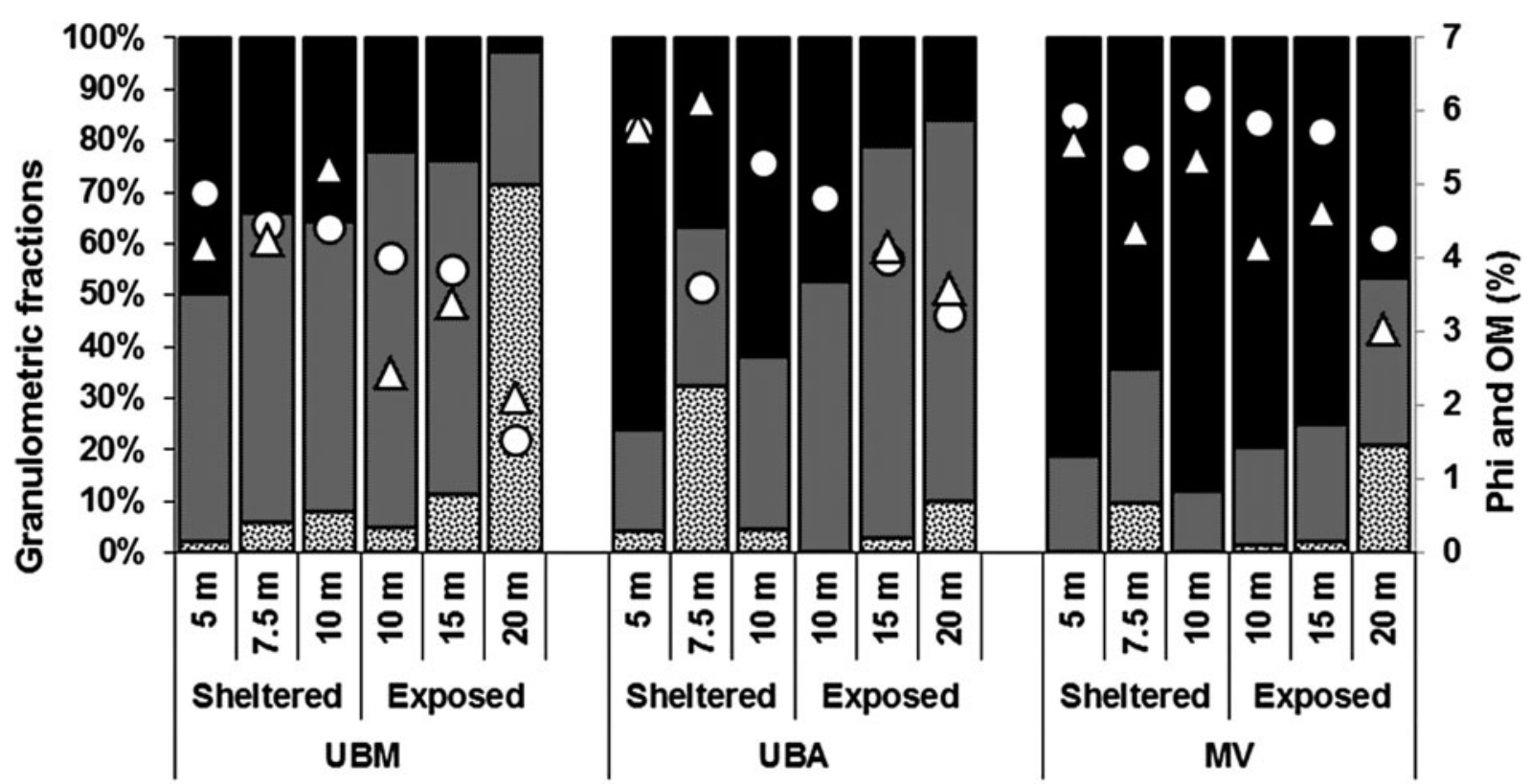

Figure 3. Proportions of grain-size classes, central tendency of bottom sediments (phi), and mean values of the organic-matter content (\% OM) for each transect in Ubatumirim (UBM), Ubatuba (UBA) and Mar Virado (MV), São Paulo State, southeastern Brazil (January 1998December 1999). A = Class A (gravel, very coarse sand, coarse sand, and intermediate sand). B $=$ Class B (fine and very fine sand). C = Class C (silt and clay).
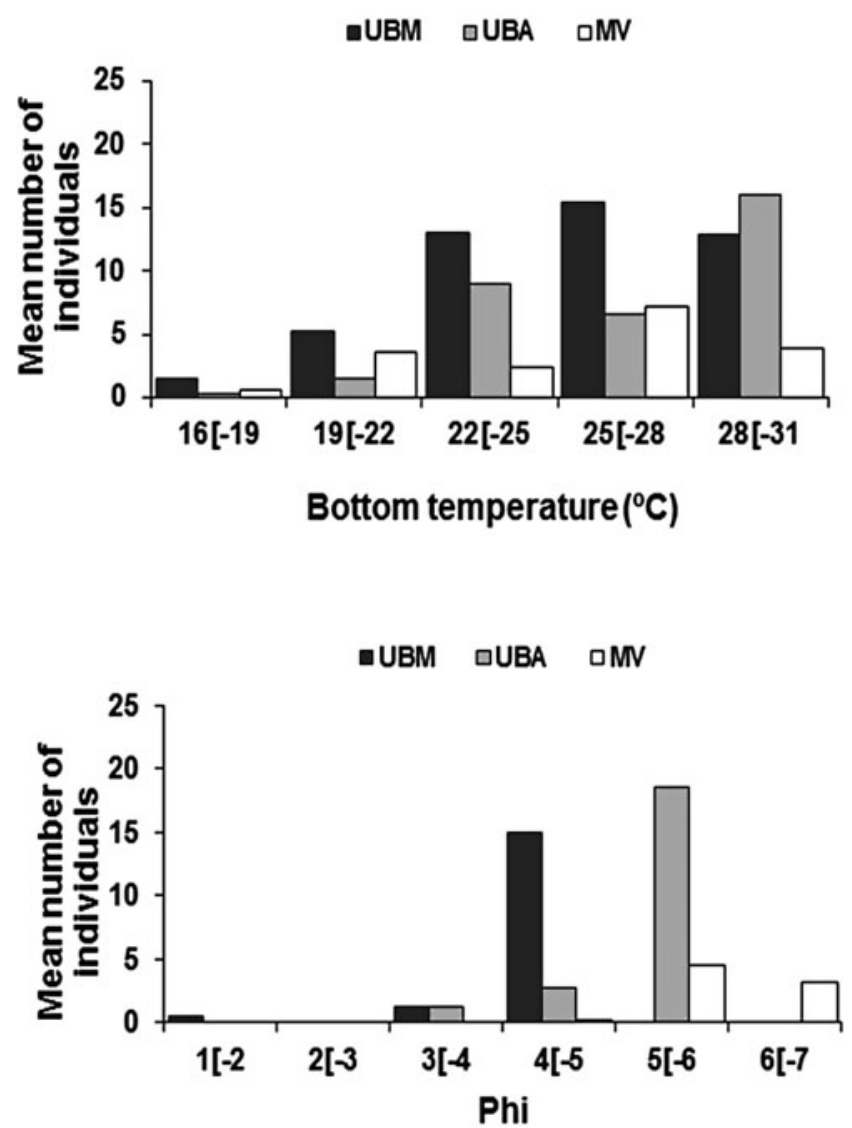
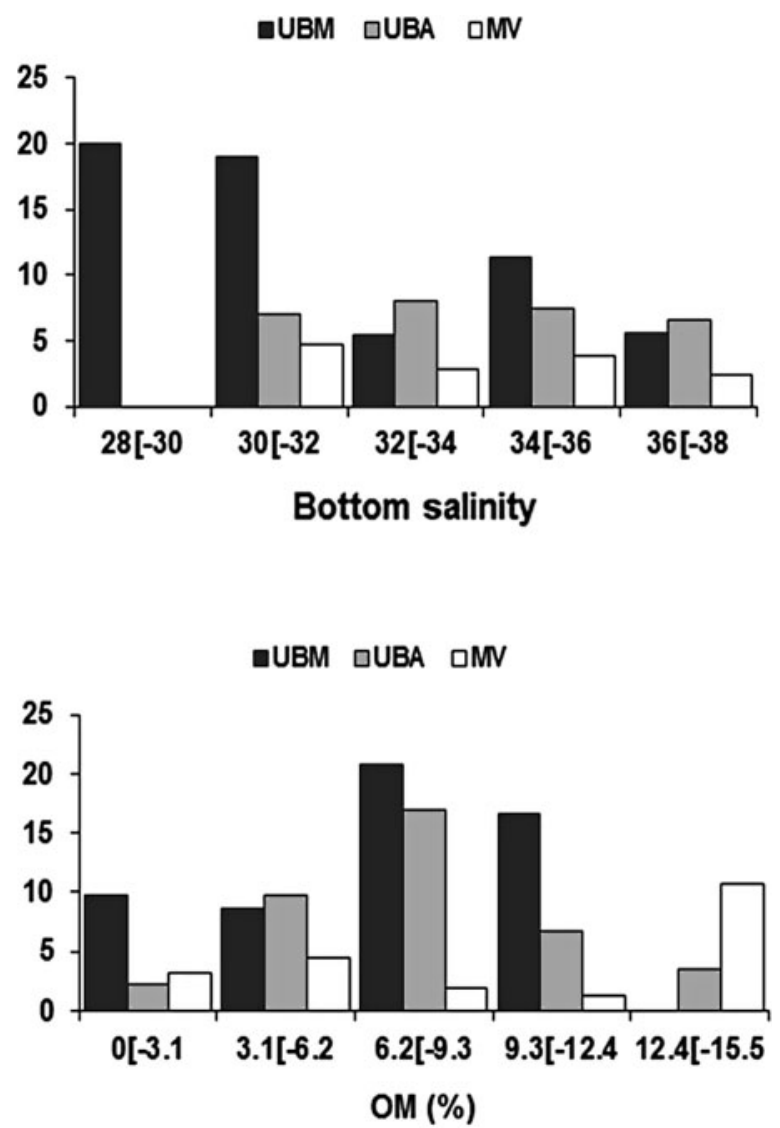

Figure 4. Callinectes danae Smith, 1869. Mean number of individuals per trawl for each class of environmental factors in Ubatumirim (UBM), Ubatuba (UBA) and Mar Virado (MV), São Paulo State, southeastern Brazil (January 1998-December 1999). OM = organic matter. 
$7.5 \mathrm{~m}$ transect of the sheltered area in UBM and MV bays. In UBM bay, the abundance was significantly the highest at the $7.5 \mathrm{~m}$ transect (865 specimens; $H=109.540, \mathrm{DF}=5, p<0.001$ ), whereas in UBA bay, the highest abundance of swimming crabs for both years occurred at the $5 \mathrm{~m}$ transect $(738$ specimens, $H=75.140, \mathrm{DF}=5, p<0.001)$, (Figure 5). Regarding the season, the highest number of individuals was recorded in the autumn (1246), which differed from the other seasons in all the sampled bays $(H=13.832, \mathrm{DF}=3, p=0.003)$ (Figure 6).

The abundance of ovigerous females and the remaining demographic groups was significantly higher at transects from sheltered areas $(H=$ 1827.500, $\mathrm{DF}=23, p \leq 0.001$ ) (Figure 7), whereas related to the seasons, ovigerous females occurred mainly during the spring and summer. The other demographic groups were observed at a higher abundance during the autumn, but the difference in the values was not significant (Figure 8).

The CCA revealed that among all environmental factors analysed, the temperature and phi values were significantly correlated with the abundance of the distinct demographic groups for $C$. danae at UBM and UBA, and only the bottom temperature at MV (Table III). The first two canonical variables, when summed, explained $83 \%$ of the variance of the distribution of $C$. danae in relation to the environmental factors at UBM, $86 \%$ at UBA and $81 \%$ at MV.

Considering the axis of the first canonical variable, the abundance of the juvenile swimming crabs was positively associated with the phi value at $\mathrm{UBM}$ and with the bottom temperature at MV, where this relationship was also positive for adult males (Figure 9).

\section{Discussion}

Based on the T-S diagram, it was observed that CWa was prevalent in the study area and that was characterized by a salinity value below 36 and temperature usually higher than $20^{\circ} \mathrm{C}$ (Castro-Filho et al. 1987), and this water mass exerted a greater effect, mostly during the autumn and winter, while the pronounced effect of the SACW occurred in the spring and summer (Costa et al. 2007).

The highest values of crab abundance during the autumn coincided with the incursion of CWa, which occurred at the transects located in the shallower areas with higher temperature values $(5,7.5$ and 10 $\mathrm{m}$ ), not influenced by the SACW (Costa et al. 2007; Castilho et al. 2015) and near to the influx of freshwater from the rivers, which contributed to the lower salinity values (Bertini et al. 2010).

The literature presents evidence of the great influence of the SACW on the populations of decapod crustaceans along the southeastern coast of Brazil (Furlan et al. 2013; Bochini et al. 2014; Andrade et al. 2015; Castilho et al. 2015). However, this influence was not relevant for this study, even with an abundance of Callinectes danae reported in spring, because the entrance of the SACW is mainly evident in exposed areas (15 and $20 \mathrm{~m}$ ) (Costa et al. 2007), where few individuals were found.

Benthic swimming crab communities of Ubatuba clearly followed a depth gradient, probably related to changes in the sediment (Sumida \& Pires-Vanin 1997). Differences in sediment grain size and organic matter content among bays and transects

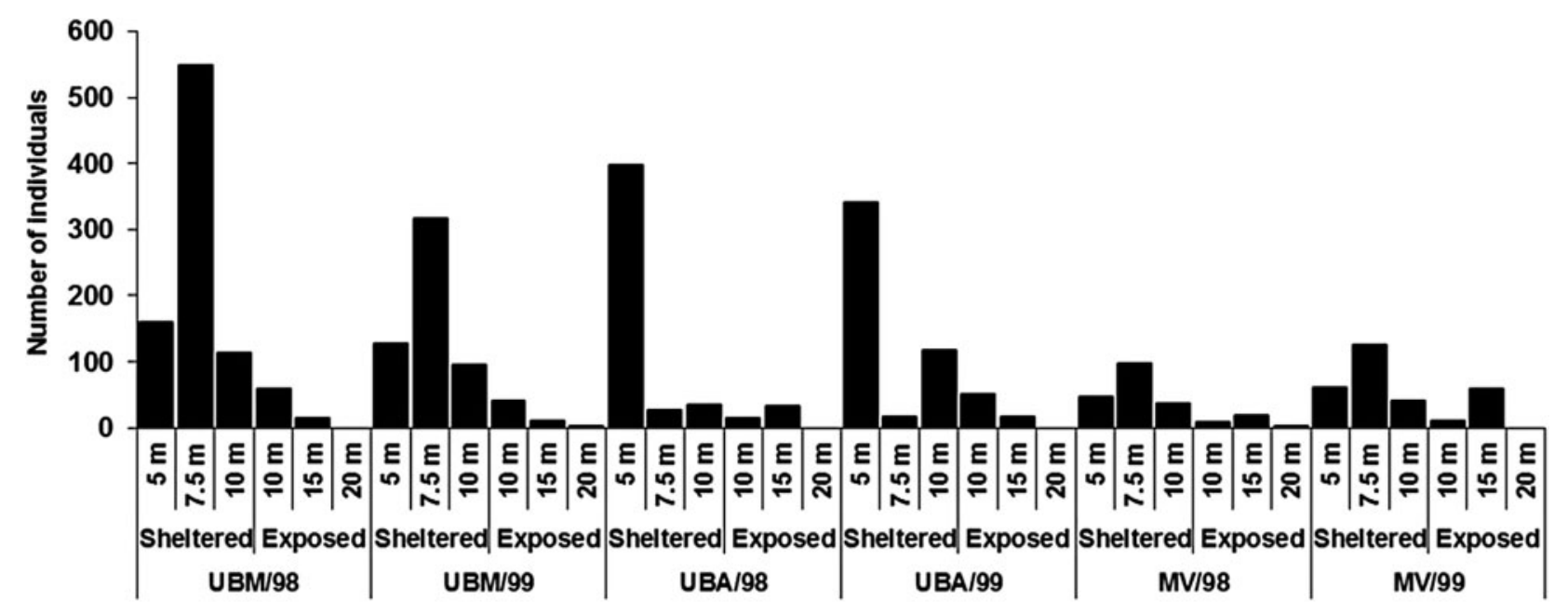

Figure 5. Callinectes danae Smith, 1869. Number of individuals in six different transects in Ubatumirim (UBM), Ubatuba (UBA) and Mar Virado (MV), São Paulo State, southeastern Brazil (January 1998-December 1999). 


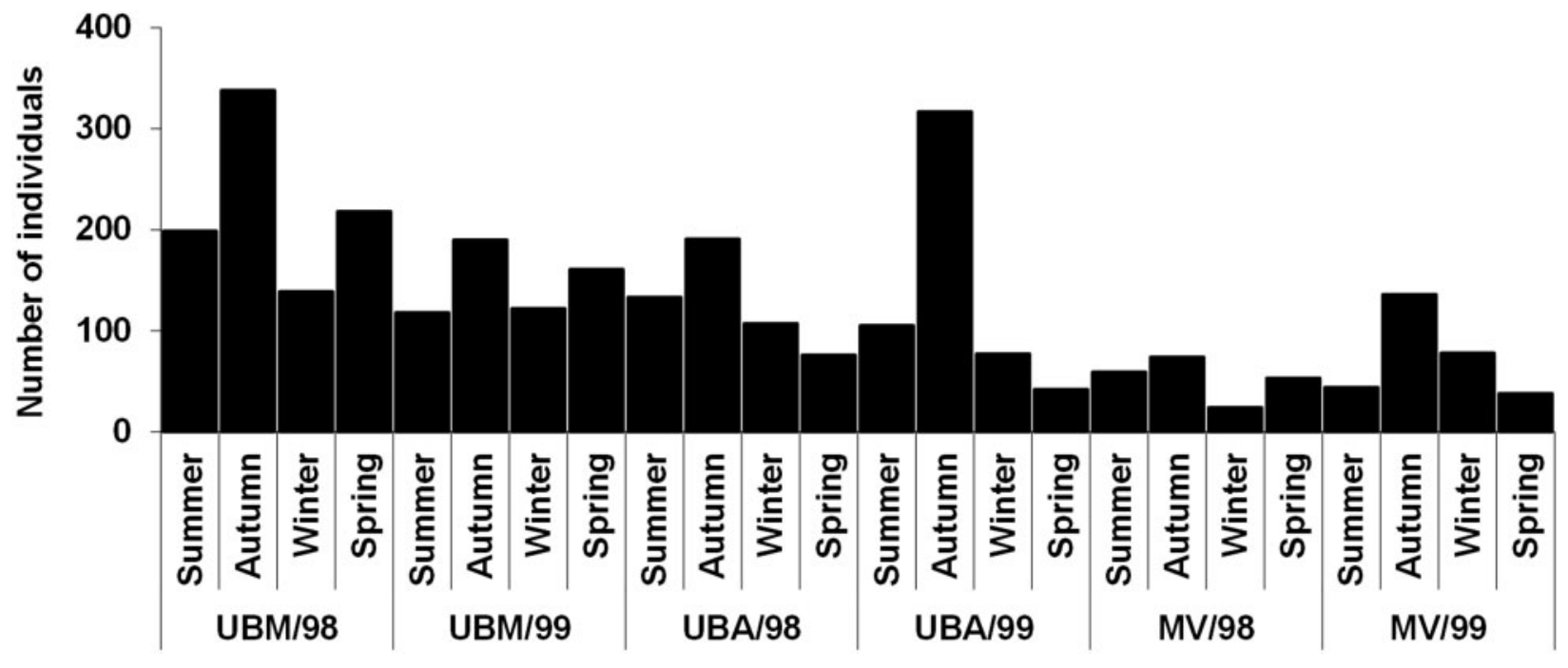

Figure 6. Callinectes danae Smith, 1869. Number of individuals in relation to the season sampled from January 1998 to December 1999 in São Paulo State, southeastern Brazil. UBM = Ubatumirim; UBA = Ubatuba; MV = Mar Virado.

also result from the local sediment dynamics, affected by the direction of ocean currents, wind and waves (Mahiques et al. 1998). The sediment texture was also an important factor that modulated the spatial distribution of $C$. danae throughout the study period. The abundance was higher in transects where the granulometric fractions were smaller,
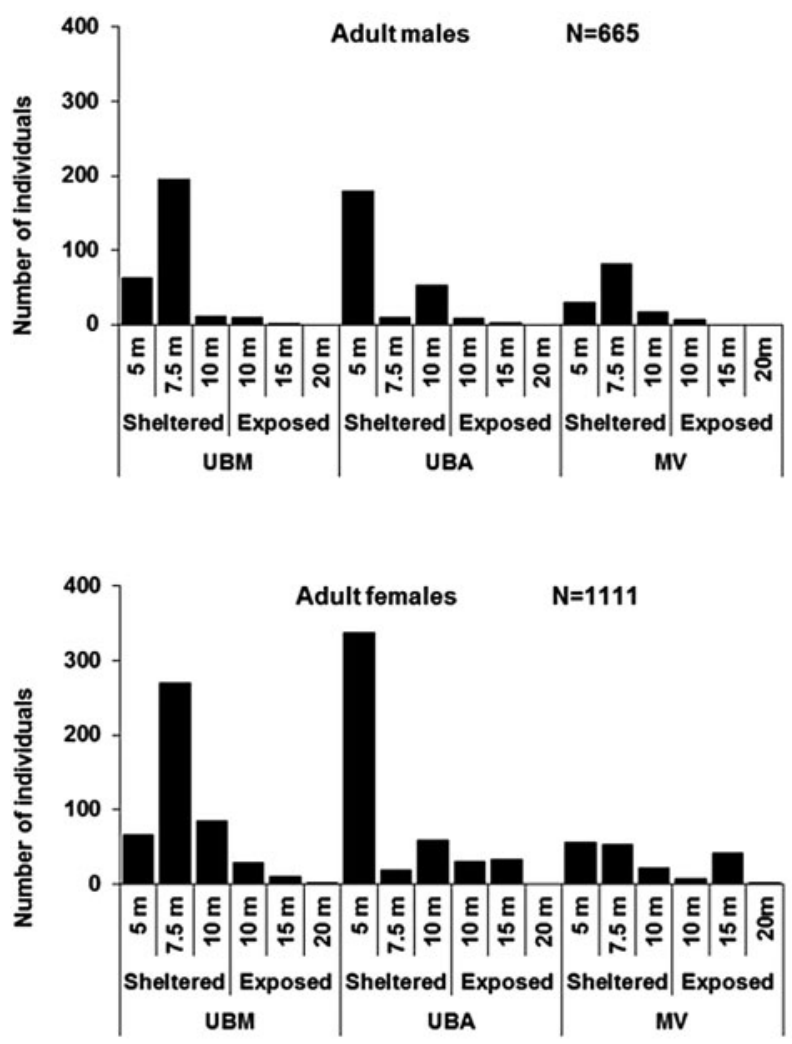

and the predominance of fine and very fine sand at UBM and UBA created more favourable conditions for the establishment of the species.

Portunids usually burrow in the sediment for protection against predators or to facilitate the capture of agile prey (Schöne 1961), such as fishes. The substrata which are predominantly mud
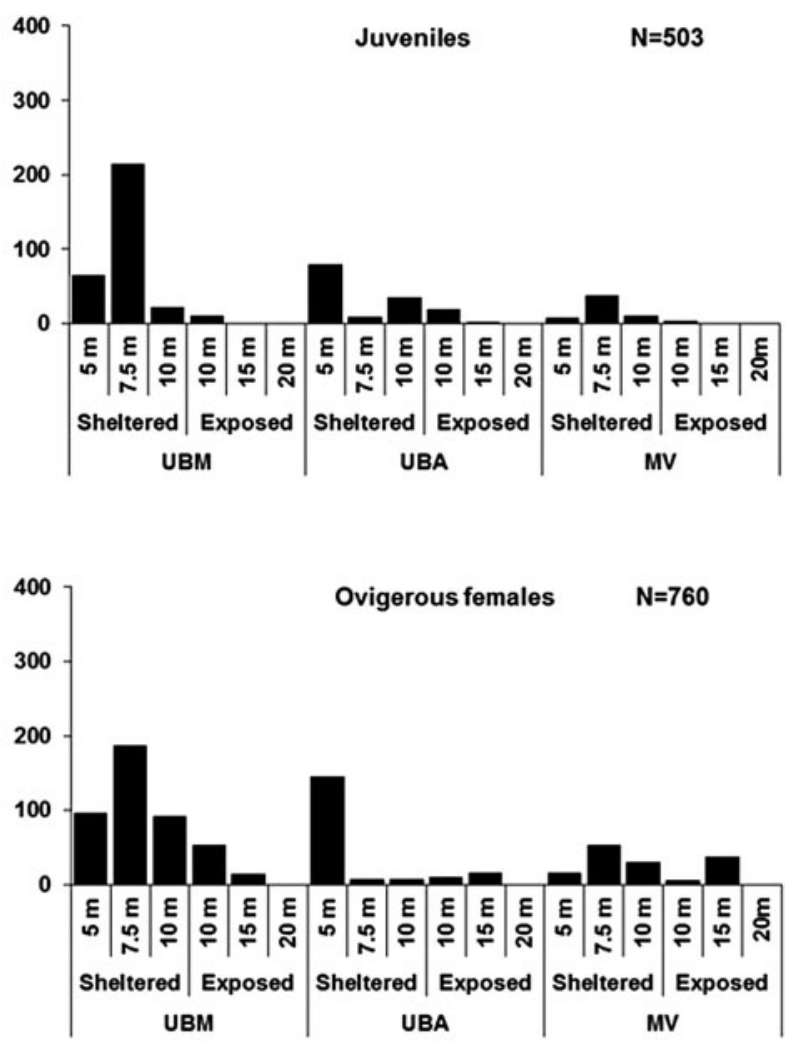

Figure 7. Callinectes danae Smith, 1869. Abundance of adult males (A), juveniles (B), adult females (C), and ovigerous females (D) in six different transects in Ubatumirim (UBM), Ubatuba (UBA) and Mar Virado (MV), São Paulo State, southeastern Brazil (January 1998December 1999). 

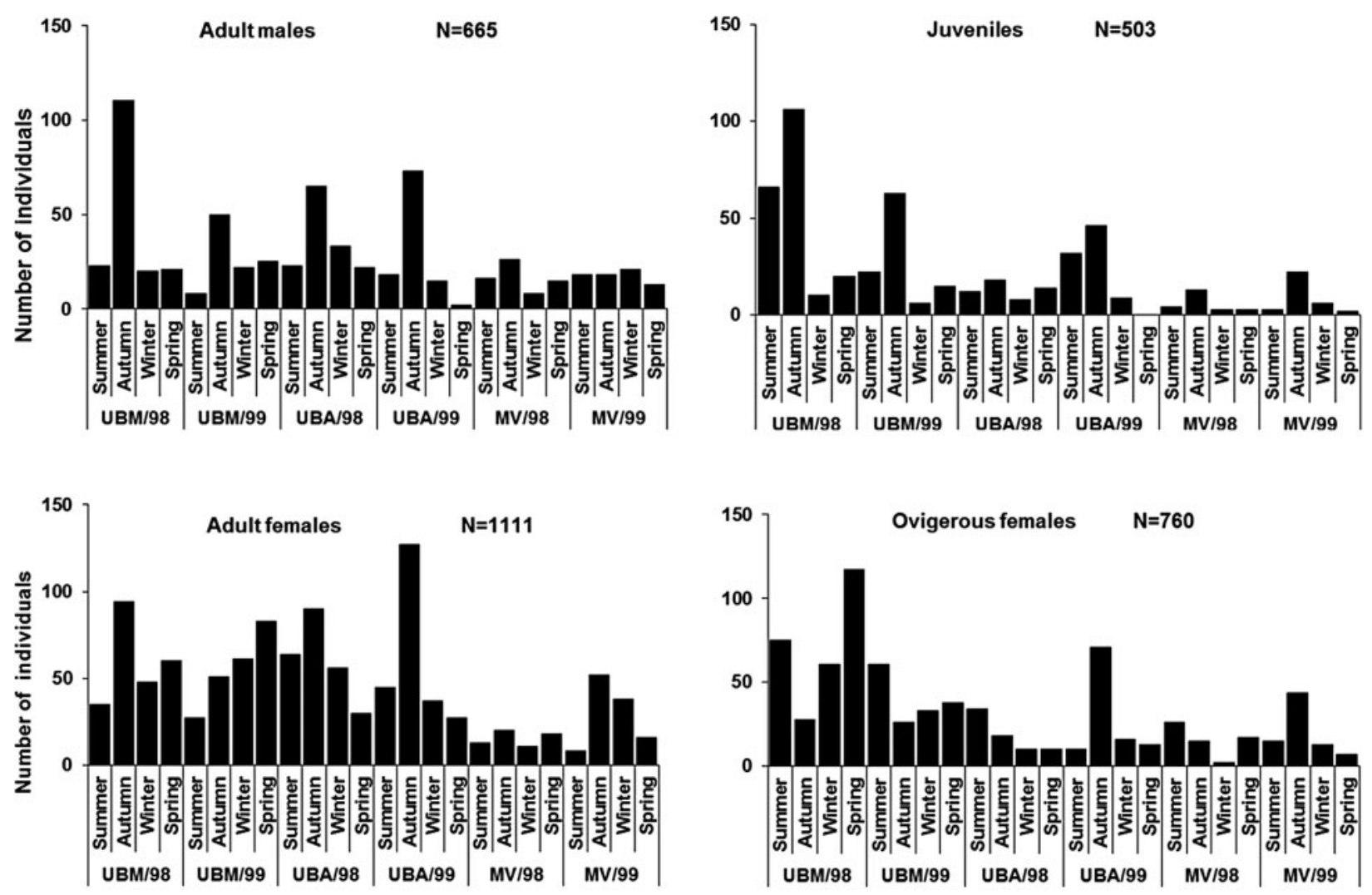

Figure 8. Callinectes danae Smith, 1869. Abundance of adult males (A), juveniles (B), adult females (C), and ovigerous females (D) in relation to seasons sampled in São Paulo State, southeastern Brazil (January 1998-December 1999). UBM = Ubatumirim; UBA = Ubatuba; MV = Mar Virado.

increase the difficulty of burrowing by swimming crabs, as well as the intake of water for gas exchange. Thus, the MV bay was not a favourable location for the establishment of $C$. danae because it contained the highest amount of silt and clay. According to Pires (1992), the bays located to the south (such as $\mathrm{MV}$ ) are less vulnerable to the action of oceanic currents and are strongly influenced by the continent due to the physical barriers formed mainly by the São Sebastião Channel and Island, and also by Anchieta and Vitória Islands. Consequently, this area showed a sedimentary deposit composed mainly of silt and clay and a higher concentration of organic matter content in the sediment.

The UBA bay had a heterogeneous sediment similar to that of UBM, but with a higher concentration of organic matter, probably because this area received domestic waste from Ubatuba City (Rodrigues et al. 2002; Bertini et al. 2010). Although swimming crabs are considered vigorous predators that mainly consume bivalves and gastropods, they also consume decomposing organic matter (Warner 1977) and can extract organic matter from the sediment. Therefore, organic matter appears not to be a limiting factor to the distribution of $C$. danae, once the individuals have distributed uniformly with respect to this environmental factor. Studies by Chacur \& Negreiros-Fransozo (2001) revealed that $C$. danae were more abundant in areas with up to $10 \%$ organic matter in the sediment, which may explain the smaller number of individuals collected in MV.

According to Negreiros-Fransozo \& Fransozo (1995), who examined the distribution of two swimming crab species of the genus Callinectes, and Pinheiro et al. (1997), who studied the portunid niche dimension and overlap, $C$. danae is preferentially found in shallow areas near estuaries, with low salinities. The large number of rivers or the large fluvial plan area can provide estuaries with favourable conditions mainly for the development of juvenile swimming crabs. The nature of the substratum, composed of finer grain sizes, food abundance and availability of refuges provided by the marginal vegetation, might favour the establishment of specimens at the transects near the mouth of such rivers (Orth \& Montfrans 1987; Williams et al. 1990; Fitz \& Wiegert 1991).

The largest estuarine area exists at UBM bay and the low anthropogenic influence might favour the high abundance of $C$. danae in this region, because this species is positively associated with freshwater 
Table III. Results of the canonical correspondence analysis ordination for the first two canonical axes, with environmental variable data and demographic category abundance from Ubatumirim, Ubatuba and Mar Virado, São Paulo State, Brazil.

\begin{tabular}{|c|c|c|c|c|}
\hline & \multicolumn{2}{|c|}{$\begin{array}{l}\text { Canonical } \\
\text { coefficients }\end{array}$} & \multirow[b]{2}{*}{$R^{2}$} & \multirow[b]{2}{*}{$p$} \\
\hline & Axis 1 & Axis 2 & & \\
\hline \multicolumn{5}{|l|}{ (A) Ubatumirim } \\
\hline \multicolumn{5}{|l|}{ Environmental variables } \\
\hline Bottom temperature $(\mathrm{T})$ & 0.554 & -0.832 & 0.254 & $0.000^{\star \star \star}$ \\
\hline Bottom salinity (S) & 0.640 & -0.768 & 0.009 & 0.645 \\
\hline Organic matter (OM) & 0.975 & -0.222 & 0.026 & 0.016 \\
\hline Phi & 0.776 & -0.629 & 0.088 & $0.015^{\star}$ \\
\hline \multicolumn{5}{|l|}{ Demographic categories } \\
\hline Juveniles $(\mathrm{J})$ & 0.948 & -0.317 & 0.424 & $0.000^{\star \star \star}$ \\
\hline Adult males (AM) & 1.000 & 0.004 & 0.255 & $0.000^{\star \star \star}$ \\
\hline Adult females (AF) & 0.486 & 0.873 & 0.189 & $0.000^{\star \star \star}$ \\
\hline Ovigerous females (OF) & -0.859 & -0.511 & 0.203 & $0.000^{\star \star \star}$ \\
\hline \multicolumn{5}{|l|}{ (B) Ubatuba } \\
\hline \multicolumn{5}{|l|}{ Environmental variables } \\
\hline Bottom temperature $(\mathrm{T})$ & 0.338 & -0.941 & 0.100 & $0.015^{\star}$ \\
\hline Bottom salinity (S) & 0.991 & -0.132 & 0.004 & 0.800 \\
\hline Organic matter (OM) & 0.681 & -0.731 & 0.019 & 0.499 \\
\hline Phi & 0.872 & -0.489 & 0.128 & $0.005^{\star \star}$ \\
\hline \multicolumn{5}{|l|}{ Demographic categories } \\
\hline Juveniles $(J)$ & 0.752 & -0.659 & 0.371 & $0.000^{\star \star \star}$ \\
\hline Adult males (AM) & 0.757 & -0.652 & 0.406 & $0.000^{\star \star \star}$ \\
\hline Adult females (AF) & 0.978 & -0.204 & 0.082 & $0.042^{\star}$ \\
\hline Ovigerous females (OF) & -0.765 & -0.643 & 0.195 & $0.000^{\star \star \star}$ \\
\hline \multicolumn{5}{|l|}{ (C) Mar Virado } \\
\hline \multicolumn{5}{|l|}{ Environmental variables } \\
\hline Bottom temperature $(\mathrm{T})$ & 0.838 & 0.545 & 0.142 & $0.003^{\star \star}$ \\
\hline Bottom salinity $(\mathrm{S})$ & -0.900 & 0.435 & 0.026 & 0.347 \\
\hline Organic matter (OM) & -0.253 & -0.967 & 0.005 & 0.801 \\
\hline Phi & -0.854 & 0.519 & 0.042 & 0.156 \\
\hline \multicolumn{5}{|l|}{ Demographic categories } \\
\hline Juveniles (J) & 0.994 & -0.103 & 0.297 & $0.000^{\star \star \star}$ \\
\hline Adult males (AM) & 0.987 & -0.159 & 0.480 & $0.000^{\star \star \star}$ \\
\hline Adult females (AF) & -0.717 & -0.696 & 0.192 & $0.000^{\star \star \star}$ \\
\hline Ovigerous females (OF) & -0.223 & 0.974 & 0.407 & $0.000^{\star \star \star}$ \\
\hline
\end{tabular}

$p=$ probability of significance based on 1000 permutations (Monte Carlo; $\alpha=0.05^{\star}$ ).

Significance codes: $0.001^{\star \star \star} ; 0.01^{\star \star} ; 0.05^{\star}$.

inputs (Pita et al. 1985). The Ubatumirim and Fazenda Rivers are near the $7.5 \mathrm{~m}$ transect $(58.2 \%$ of all individuals captured), the Iriri and da Onça Rivers are near the $5 \mathrm{~m}$ transect $(19 \%$ of all individuals), and Puruba and Quiririm Rivers are near the $10 \mathrm{~m}$ transect (sheltered area) (14\% of all individuals).

In UBA bay, the highest abundance of all individuals of $C$. danae was recorded along the $5 \mathrm{~m}$ transect, situated near the Lagoa, Grande and Acaraú Rivers. Although UBA is considered to experience the highest anthropogenic influence of the bays studied, the estuarine area formed by these rivers favoured the abundance of $C$. danae, as $34.4 \%$ of the total swimming crabs sampled in this study were obtained in this bay. Bertini et al. (2010) also noted a high occurrence of $C$. danae in the more sheltered transects of these bays and attributed this occurrence to the particular features of such places, which showed oscillations in salinity due to the flow of small rivers in the area, as well as facilitating the entrance of such organisms in the estuary, where they can grow and subsequently mate.

The migratory behaviour of ovigerous and adult females from shallower and estuarine regions to deeper sites was observed for $C$. danae for several regions of the Brazilian coast (Pita et al. 1985; Branco \& Masunari 2000; Baptista-Metri et al. 2005) and is closely related to the reproductive success of this species that can vary depending on the size of the estuarine areas, as well as on the conservation status and the intensity of fishing in the area (Sforza et al. 2010; Sant'Anna et al. 2012).

In the Santos and São Vicente (State of São Paulo) estuarine areas, the highest exploitation of swimming crabs by fishing occurs in the inner region of the estuaries, by small artisanal fishery communities. In such activities, adult males represent the highest percentage of capture, followed by immature females (in the mature pre-moult phase) (SeverinoRodrigues et al. 2001). The ovigerous females remain concentrated in the deeper regions of the bays to ensure spawning and larval hatching (Pita et al. 1985). Additionally, Branco \& Masunari (2000) reported that the Conceição Lagoon (State of Santa Catarina) also served as a spawning area for C. danae, and Baptista-Metri et al. (2005) reported that areas of shrimp exploitation also coincided with the spawning area for $C$. danae at Shangri-lá, Pontal do Paraná (State of Paraná).

In the three bays studied there was intensive artisanal fishing and this overlapped areas where there was a high abundance of ovigerous females. The fact that a large number of crabs are caught in the artisanal fishery might influence or modulate changes in abundance of the populations of C. danae. In agreement with Sant'Anna et al. (2012), special attention must be paid to the management of these estuarine areas, mainly during the reproduction peaks, due to the presence of a high concentration of pre-ovigerous and ovigerous females, which are positively associated with freshwater inputs (Pita et al. 1985). The preservation of these estuarine areas and adjacent bays is fundamental to the maintenance of population stocks of C. danae.

The complex life cycle of this swimming crab species in estuarine areas that are impacted by fishery and touristic development is a potential problem. The high abundance observed for this species at UBM might be related to the fact that 
A

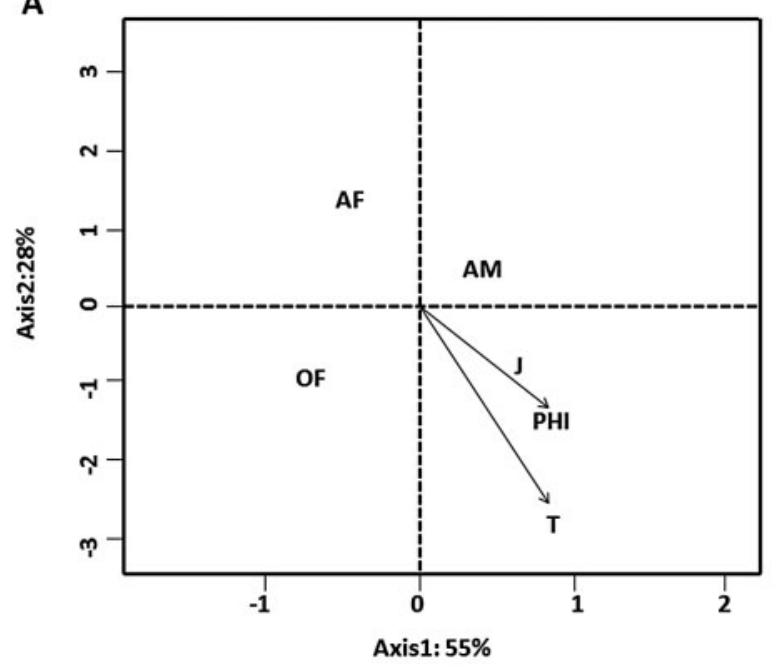

B

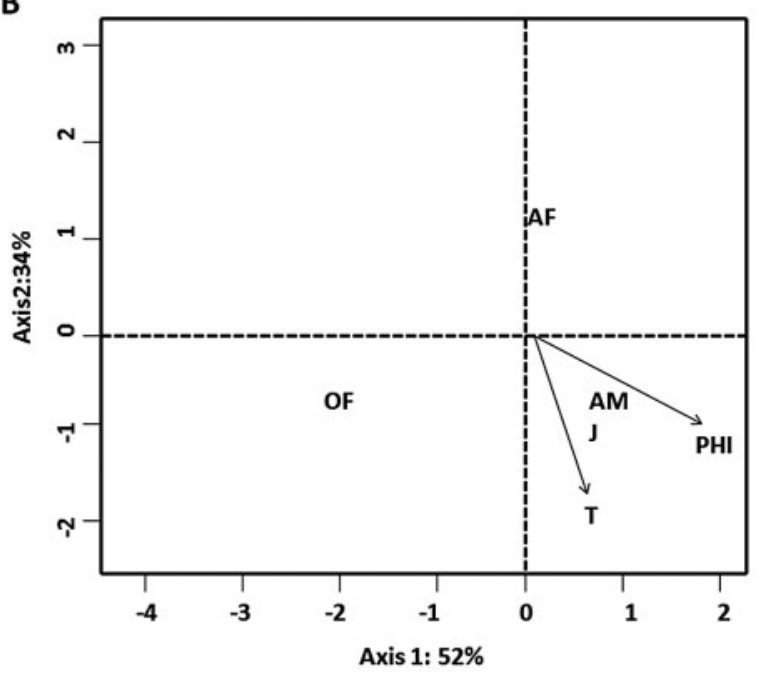

C

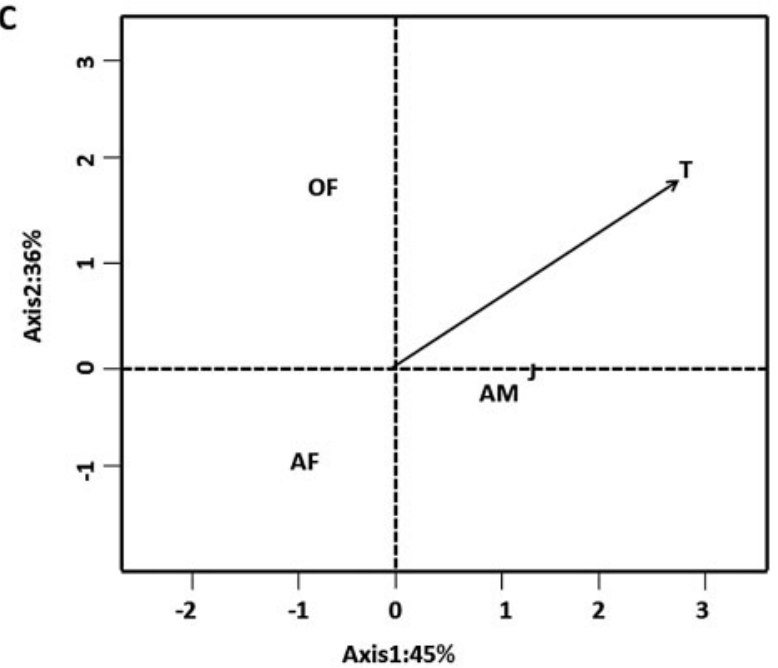

Figure 9. Callinectes danae Smith, 1869, from Ubatumirim, Ubatuba, and Mar Virado, São Paulo State, southeastern Brazil (January 1998-December 1999). Bidimensional graphics resulting from the canonical correspondence analysis between environmental variables and the abundance of demographic categories $(\mathrm{J}=$ juveniles; $\mathrm{AM}=$ adult males; $\mathrm{AF}=$ adult females; $\mathrm{OF}=$ ovigerous females; $\mathrm{T}=$ bottom temperature; $\mathrm{S}=$ bottom salinity; $\mathrm{OM}=$ organic matter). this bay is an environment that has little impact by human occupation and anthropogenic activity (Rodrigues et al. 2002).

Several studies have shown evidence of the differential distribution of demographic groups of $C$. danae, especially ovigerous females and adult nonovigerous females that probably migrated to deeper places with higher salinities to release their larvae. Larval dispersal is favoured in deeper waters due to the action of currents and winds (Hines et al. 1987; Chacur \& Negreiros-Fransozo 2001; Sforza et al. 2010). Larvae in a more advanced stage of development return to shallow areas with lower salinity to complete their life cycles (Chacur \& NegreirosFransozo 2001). However, in our study all groups were well represented, especially in shallow transects, indicating that the sampled areas provided adequate conditions for the presence of individuals at all benthic stages of the life cycle of $C$. danae.

The results of the present study showed that the migration of ovigerous females, mentioned by other authors, might occur only for a proportion of females of a particular area. Moreover, shallow estuaries and adjacent environments studied here provided conditions for the coexistence of all demographic groups of the $C$. danae population.

\section{Acknowledgements}

We thank the NEBECC co-workers for their help during the fieldwork and Maria Lucia NegreirosFransozo for her constructive comments on early drafts of the manuscript. This research was accomplished according to current Brazilian state and federal laws concerning wild animal sampling.

\section{Disclosure statement}

No potential conflict of interest was reported by the authors.

\section{Funding}

The authors are grateful to the São Paulo Research Foundation (FAPESP) for providing financial support (grant numbers 94/4878-8, 97/12108-6, 97/12106-3, 97/ $12107-0$ and $98 / 3134-6)$.

\section{References}

Ab'Saber AN. 1955. Contribuições à geomorfologia do litoral paulista. Revista Brasileira de Geografia 17:3-37.

Almeida AC, Fransozo A, Teixeira GM, Hiroki KAN, Furlan M, Bertini G. 2012. Ecological distribution of the shrimp Nematopalaemon schmitti (Crustacea: Decapoda: Caridea) in three bays on the south-eastern coast of Brazil. African Journal of Marine Science 34:93-102.

Andrade LS, Frameschi IF, Costa RC, Castilho AL, Fransozo A. 2015. The assemblage composition and structure of swimming 
crabs (Portunoidea) in continental shelf waters of southeastern Brazil. Continental Shelf Research 94:8-16.

Baptista-Metri C, Pinheiro MAA, Blankensteyn A, Borzone CA. 2005. Biologia populacional e reprodutiva de Callinectes danae Smith (Crustacea, Portunidae), no Balneário de Shangri-lá, Pontal do Paraná, Paraná, Brasil. Revista Brasileira de Zoologia 22:446-53.

Bertini G, Fransozo A, Costa RC. 2001. Ecological distribution of three species of Persephona (Brachyura, Leucosiidae) in the Ubatuba region, São Paulo, Brazil. Nauplius 9:31-42.

Bertini G, Fransozo A, Negreiros-Fransozo ML. 2010. Brachyuran soft-bottom assemblage from marine shallow waters in the southeastern Brazilian littoral. Marine Biodiversity 40:277-91.

Bochini GL, Fransozo A, Castilho AL, Hirose GL, Costa RC. 2014. Temporal and spatial distribution of the commercial shrimp Litopenaeus schmitti (Dendrobranchiata: Penaeidae) in the south-eastern Brazilian coast. Journal of the Marine Biological Association of the United Kingdom 94:1001-08.

Branco JO, Masunari S. 2000. Reproductive ecology of the blue crab, Callinectes danae Smith, 1869 in the Conceição Lagoon System, Santa Catarina Isle, Brazil. Revista Brasileira de Zoologia 60:17-27.

Branco JO, Lunardon MJ, Loyola e Silva J, Avila MG. 1992. Observações bioecológicas sobre o "siri azul" Callinectes danae Smith, 1869 (Decapoda, Portunidae) da Baía Norte, SC, Brasil. Brazilian Archives of Biology and Technology 35:557-46.

Buchanan BA, Stoner AW. 1988. Distribution patterns of blue crabs (Callinectes sp.) in a tropical estuarine lagoon. Estuaries 11:231-39.

Carvalho FL, Couto ECG. 2011. Environmental variables influencing the Callinectes (Crustacea: Brachyura: Portunidae) species distribution in a tropical estuary - Cachoeira River (Bahia, Brazil). Journal of the Marine Biological Association of the United Kingdom 91:793-800.

Castilho AL, Furlan M, Costa RC, Fransozo V. 2008a. Reproductive biology of the rock shrimp Sicyonia dorsalis (Decapoda: Penaeoidea) from the southeastern coast of Brazil. Invertebrate Reproduction and Development 52:59-68.

Castilho AL, Pie MR, Fransozo A, Pinheiro AP, Costa RC. 2008b. The relationship between environmental variation and species abundance in shrimp community (Crustacea: Decapoda: Penaeoidea) in south-eastern Brazil. Journal of the Marine Biological Association of the United Kingdom 88:119-23.

Castilho AL, Bauer RT, Freire FAM, Fransozo V, Costa RC, Grabowski RC, Fransozo A. 2015. Lifespan and reproductive dynamics of the commercially important sea bob shrimp Xiphopenaeus kroyeri (Penaeoidea): Synthesis of a 5-year study. Journal of Crustacean Biology 35:30-40.

Castro-Filho BM, Miranda LB, Myao SY. 1987. Condições hidrográficas na plataforma continental ao largo de Ubatuba: Variações sazonais e em média escala. Boletim do Instituto Oceanográfico 35:135-51.

CETESB (Companhia de Tecnologia de Saneamento Ambiental). 1996. Relatório de Balneabilidade das Praias Paulistas-1995. São Paulo: Secretaria do Meio Ambiente. 112 pages.

Chacur MM, Negreiros-Fransozo ML. 2001. Spatial and seasonal distributions of Callinectes danae (Decapoda, Portunidae) in Ubatuba Bay, São Paulo, Brazil. Journal of Crustacean Biology $21: 414-25$.

Chacur MM, Mansur CB, Negreiros-Fransozo ML. 2000. Distributional patterns, seasonal abundance and moult cycle of Callinectes danae Smith, 1869 in the Ubatuba region, Brazil. Nauplius 8:215-26.

Clucas I. 1998. La fauna acompanãnte? És una bonificación del mar? Infopesca International 38:33-37.
Costa RC, Fransozo A, Freire FAM, Castilho AL. 2007. Abundance and ecological distribution of the 'sete-barbas' shrimp Xiphopenaeus kroyeri (Heller, 1862) (Decapoda: Penaeoidea) in three bays of the Ubatuba region, southeastern Brazil. Gulf and Caribbean Research 19:33-41.

Costa TM, Negreiros-Fransozo ML. 1998. The reproductive cycle of Callinectes danae Smith, 1869 (Decapoda, Portunidae) in the Ubatuba region, Brazil. Crustaceana 71:615-27.

De Léo FC, Pires-Vanin AMS. 2006. Benthic mega fauna communities under the influence of the South Atlantic Central Water intrusion on to the Brazilian SE shelf: A comparison between an upwelling and a non-upwelling ecosystem. Journal of Marine Systems 60:268-84.

FAO. 1994. Report of the expert consultation on the code of conduct for responsible fishing - fishing operations. Sidney, BC, Canada, 6-11 June 1994. FAO Fisheries Report 506:1-16.

Fitz HC, Wiegert RG. 1991. Utilization of the intertidal zone of salt marsh by the blue crab Callinectes sapidus: Density, return frequency and feeding habitats. Marine Ecology Progress Series 76:249-60.

Fransozo A, Negreiros-Fransozo ML, Mantelatto FLM, Pinheiro MAA, Santos S. 1992. Composição e distribuição dos Brachyura (Crustacea, Decapoda) do sublitoral não consolidado na Enseada da Fortaleza, Ubatuba (SP). Revista Brasileira de Biologia 52:667-75.

Furlan M, Castilho AL, Fernandes-Góes LC, Fransozo V, Bertini G, Costa RC. 2013. Effect of environmental factors on the abundance of decapod crustaceans from soft bottoms off southeastern Brazil. Anais da Academia Brasileira de Ciências 85:1345-56.

Haefner Jr PA. 1990. Morphometry and size at maturity of Callinectes ornatus (Brachyura, Portunidae) in Bermuda. Bulletin of Marine Science 46:264-86.

Hines AH, Lipicius RN, Haddon AM. 1987. Population dynamics and habitat partitioning by size, sex, and molt stage of blue crabs Callinectes sapidus in a sub-estuary of central Chesapeake Bay. Marine Ecology Progress Series 36:55-64.

Keunecke KA, Silva Jr DR, Vianna M, Verani JR, D'Incao F. 2008. Effects of migration activity on the mortality rates of two Portunidae crabs in a tropical bay. Marine Biodiversity Records 2:34-38.

Lipcius RN, Van Engel WA. 1990. Blue crab population dynamics in the Chesapeake Bay: Variation in abundance (York River, 1972-1988) and stock-recruit functions. Bulletin of Marine Science 46:180-94.

Loebmann D, Vieira JP. 2006. O impacto da pesca do camarão rosa Farfantepenaeus paulensis (Perez-Farfante) (Decapoda, Penaeidae) nas assembléias de peixes e siris do Parque Nacional da Lagoa do Peixe, Rio Grande do Sul, Brasil. Revista Brasileira de Zoologia 23:1016-28.

Mahiques MM. 1995. Dinâmica sedimentar atual nas enseadas da região de Ubatuba, Estado de São Paulo. Boletim do Instituto Oceanográfico 43:111-22.

Mahiques MM, Tessler MG, Furtado VV. 1998. Characterization of energy gradient in enclosed bays of Ubatuba region, South-eastern Brazil. Estuarine, Coastal and Shelf Science 47:431-46.

Mantelatto FLM, Fransozo A. 1997. Fecundity of the crab Callinectes ornatus Ordway, 1863 (Decapoda, Brachyura, Portunidae) from the Ubatuba region, São Paulo, Brazil. Crustaceana 70:214-26.

Mantelatto FLM, Fransozo A. 1999. Reproductive biology and moulting cycle of the crab Callinectes ornatus (Decapoda, Portunidae) from the Ubatuba region, São Paulo, Brazil. Crustaceana 72:63-76.

McClintock JB, Marion KR, Dindo J, Hsueh PW, Angus RA. 1993. Population studies of blue crabs in soft-bottom, 
unvegetated habitats of a subestuary in the northern Gulf of Mexico. Journal of Crustacean Biology 13:551-63.

Melo GAS. 1996. Manual de Identificação dos Brachyura (Caranguejos e Siris) do Litoral Brasileiro. São Paulo: Plêiade/FAPESP. 604 pages.

Melo GAS, Veloso VG, Oliveira MC. 1989. A fauna de Brachyura (Crustacea: Decapoda) do litoral do Estado do Paraná. Lista Preliminar. Nerítica 4:1-31.

Negreiros-Fransozo ML, Fransozo A. 1995. On the distribution of Callinectes ornatus Ordway, 1863 and Callinectes danae Smith, 1869 (Brachyura, Portunidae) in the Fortaleza Bay, Ubatuba, Brazil. Iheringia, Série Zoologia 79:13-25.

Ng PKL, Guinot D, Davie PJF. 2008. Systema Brachyurorum: Part I. An annotated checklist of the extant brachyuran crabs of the world. The Raffles Bulletin of Zoology 17:1-286.

Norse EA. 1977. Aspects of the zoogeographic distribution of Callinectes (Brachyura: Portunidae). Bulletin of Marine Science 27:440-47.

Odebrecht C, Castello JP. 2001. The convergency ecosystem in the southwest Atlantic. In: Seeliger U, Kjerfve B, editors. Coastal Marine Ecosystems of Latin America. Ecological Studies 144. Berlin, Heidelberg: Springer, p 147-65.

Orth RJ, Montfrans van J. 1987. Utilization of a seagrass meadow and tidal marsh creek by blue crabs Callinectes sapidus. I. Seasonal and annual variations in abundance with emphasis on post-settlement juveniles. Marine Ecology Progress Series 41:283-94.

Paul RKG. 1982. Observation on the ecology and distribution of swimming crabs of the genus Callinectes in the Gulf of California, Mexico. Crustaceana 42:96-100.

Pinheiro MAA, Fransozo A, Negreiros-Fransozo ML. 1997. Dimensionamento e sobreposição de nichos dos Portunídeos (Decapoda, Brachyura) na Enseada da Fortaleza, Ubatuba, São Paulo, Brasil. Revista Brasileira de Zoolologia 14:371-78.

Pires AMS. 1992. Structure and dynamics of benthic megafauna on the continental shelf offshore of Ubatuba, southeastern Brazil. Marine Ecology Progress Series 86:63-76.

Pires-Vanin AMS, Matsuura Y. 1993. Estrutura e função do ecossistema de plataforma continental da região de Ubatuba, Estado de São Paulo: Uma introdução. Boletim do Instituto Oceanográfico 10:1-8.

Pita JB, Rodrigues ES, Graça-Lopes R, Coelho JAP. 1985. Levantamento da família Portunidae (Crustacea, Decapoda, Brachyura) no complexo baía-estuário de Santos, São Paulo, Brasil. Boletim do Instituto Oceanográfico 12:153-62.
Powers LW. 1977. A catalogue and bibliography to the crabs (Brachyura) of the Gulf of Mexico. Contributions in Marine Science 20:1-190.

Rodrigues M, Mahiques MM, Tessler MG. 2002. Sedimentação atual nas enseadas de Ubatumirim e Picinguaba, região norte de Ubatuba, Estado de São Paulo, Brasil. Revista Brasileira de Oceanografia 50:27-45.

Sant'Anna BS, Turra A, Zara JF. 2012. Reproductive migration and population dynamics of the blue crab Callinectes danae in an estuary in southeastern Brazil. Marine Biology Research 8:354-62.

Schöne H. 1961. Complex behavior. In: Waterman TH, editor. The Physiology of Crustacea. Volume II. Sense Organs, Integration and Behaviour. New York: Academic Press, p 465-520.

Severino-Rodrigues E, Pita JB, Graça-Lopes R. 2001. Pesca artesanal de siris (Crustacea, Decapoda, Portunidae) na região estuarina de Santos e São Vicente (SP), Brasil. Boletim do Instituto de Pesca 27:7-19.

Sforza R, Nalesso RC, Joyeux JC. 2010. Distribution and population structure of Callinectes danae (Decapoda: Portunidae) in a tropical Brazilian estuary. Journal of Crustacean Biology 30:597-606.

Suguio K. 1973. Introdução à Sedimentologia. São Paulo: Edgard Blucher: EDUSP. 317 pages.

Sumida PYG, Pires-Vanin AMS. 1997. Benthic associations of the shelf break and upper slope off Ubatuba-SP, south-eastern Brazil. Estuarine, Coastal and Shelf Science 44:779-84.

Warner GF. 1977. The Biology of Crabs. London: Eleck Science. 202 pages.

Wentworth CK. 1922. A scale of grade and class terms for clastic sediments. Journal of Geology 30:377-92.

Williams AB. 1974. The swimming crabs of the genus Callinectes (Decapoda: Portunidae). Fishery Bulletin 72:685-798.

Williams AH, Coen LD, Stoelting MS. 1990. Seasonal abundance, distribution and habitat selection of juvenile Callinectes sapidus in the northern Gulf of Mexico. Journal of Experimental Marine Biology and Ecology 137:165-83.

Zar JH. 1999. Biostatistical Analysis. 4th edition. Upper Saddle River, NJ: Prentice Hall. 663 pages.

Editorial responsibility: Ingo Wehrtmann 